\title{
THE FUTURE OF THE MANUSCRIPT AND RARE BOOK BUSINESS ${ }^{1}$
}

Winston Churchill is OfTen, though erroneously, quoted as saying that those who don't read history will be condemned to relive it. This is true in many senses and is based on human beings reacting in natural and predictable ways regardless of the time frame. In considering the future of the manuscript and rare book world, however, it is important to understand its history partly because many assumptions of today's dealers are based on what was, not on what is and what will be. Every aspect of the business has changed dramatically in recent times. I emphasize the business-not the love and appeal of the material. Many of the business factors cannot be changed by dealers. The challenge of the future is to utilize as many as possible and to adapt to the rest. One of the challenges of the future is that many dealers are caught up in the ultimately terminal illness of our field, remembering the "good old days." Although all of us are, to some degree, in the history business, it might be said that nostalgia just isn't what it used to be.

To begin, it's important to know my perspective. I started in 1959 and am now one of only several dealers from 40 years ago still actively running a full-time business. I was a collector, with neither the money nor the social connections to propel me into the business. My main asset was my collector's perspective. I had to find a niche that was not filled by others; in the 1960s, there were more full-time autograph and 
manuscript dealers than there are today. I started from a precarious base, not an entrenched one; and this is part of the reason I have always been concerned about and interested in how the field is changing.

We have two sections to our business: our New York gallery that offers framed letters and documents, signed books, and a relatively small selection of rare books; and our Boston office that handles letters and manuscripts with important contents, handles archives, and forms libraries for private collectors. Until about five years ago, we only occasionally handled printed books.

I will probably surprise many of you by stating that I enjoy this business more today than I have at any other time in the past 40 years. The collectors we deal with today are more appreciative, responsive, and interested than any previous generation. This is an important part of my perspective.

My talk is not to reminisce about the good old days, how all of the good materials have disappeared from the market, what comes up goes to auction, collectors are both uneducated and interested only in high spots, and, in general, the whole field has gone to hell. Although some of this may be true, I want to discuss briefly the major changes I've seen, how we have evolved into our present situation, how the major areas and factors are likely to evolve in the future, and, most important, what dealers can do to be successful in the changing and challenging times ahead.

When this subject was talked about at the Los Angeles ILAB/LILA ${ }^{2}$ meeting several years ago, in an atmosphere of doom and gloom, a dealer very eloquently disagreed, stating that he very much enjoyed the 
business and was quite satisfied with its current state. The dealer's point of view was right for his situation, and my remarks are not intended for those who see no undesirable changes and have no concerns about the future. For many in this field, it is a part-time business, a retirement hobby or one supported by other income. My remarks are intended for those who are concerned about the future, the lack of new interest in their specialties, and, most of all, the difficulty in finding new collectors. Many dealers who have families to raise, mortgages to pay, and business expenses much higher than those long established are intelligently concerned about the future.

Our past is an important part of understanding our future. There are both logical and illogical connections and disconnections between our past, our present, and our probable future. We can accurately forecast that the cost of retail space in high-visibility areas that will attract new collectors is going to continue to rise. We can also see by looking at the statistics of college studies that tomorrow's potential collectors are not going to be as well-educated, in our sense, as those in the past.

More important, I think some traditions in the history of the rare book business affect the attitudes of dealers today in ways that are negative. In reading the memoirs of rare book and manuscript dealers, few would realistically identify with the material they handled. But many identify with an attitude of the role of the dealer that I believe is an anathema to potential collectors today. Among the business factors that I am going to discuss tonight, this is one of the most important because it is in the dealer's power to change it.

During the 1960s and well into the 1970s, autograph and manuscript collectors fell into three categories. Institutions were overwhelmingly the major clients, followed by what I call the "professional" collectors, such as Waller Barrett in New York, Jim Osborn at Yale, and Bob Taylor at Princeton, who systematically formed subject and author collections 
in the same manner as institutional libraries; and finally, the private collectors, who were, with the exception of Phil Sang, the minority in percentage of sales.

There was a steady flow of very fine manuscript material from the families of recipients onto the market. Institutions were well funded, and we made monthly on-approval shipments (it was too time-consuming to quote material before the invention of copying machines). Private collectors were mainly set-oriented: signers of the Declaration of Independence, the presidents, royalty, and also the signers of what are now obscure documents such as the Albany Convention and even prime ministers. A few formed subject collections such as the American Revolution or the Civil War; you could then assemble large and significant collections relatively inexpensively.

Most of the major dealers had street-level retail locations in major cities and were instrumental in creating new collectors. Warren Howell in San Francisco, Jake Zeitlin in Los Angeles, H. P. Kraus and Charles Hamilton in New York, Mabel Zahn in Philadelphia, Ken Nebenzahl in Chicago, and many others developed collectors who eventually flowed into the mainstream of the business.

Dealers' retail locations were the principal means of creating new collectors, not advertising or book fairs. A prospective collector was enticed by a window display and then met a very magnetic and dynamic dealer who shared their own passion for the field. Special collections librarians also had an influence by sharing their passion with students and visitors. There was also a social factor. Much of Goodspeed's business was initiated and concluded by George Goodspeed in the private clubs of Boston.

The dealers bought the major collections. The auction house (there was only one) was wonderfully passive. Its attitude was wholesaling, and it 
referred collectors to dealers who would act as agents. It was even reputed that Park Bernet once cataloged a "box of contents." Book fairs were so unimportant that in the mid-sixties the New York Book Fair was canceled because we couldn't get 20 exhibitors. A successful fair, which was held at the Plaza Hotel every two years, consisted of 25 dealers.

The major changes from this state of affairs began in the mid- to late1970s. Years of massive purchases by institutions caused entire subject areas to disappear from the market. Waller Barrett could only buy American literature for so long before the archives and attics of America were literally emptied. Then, the Humanities Research Center at Austin, now the Harry Ransom Humanities Research Center, sought out the living correspondents of the modern authors they were collecting and offered to buy their papers. What had been a very plentiful market in literary material slowed to a trickle.

As the historical collections formed in the 1950s and 1960s came onto the market, a collection formed by one person would be sold to 50 or so different collectors. A major collection of Revolutionary War material which, in 1960, might consist of 300-400 letters would now be defined as consisting of 30 or 40 pieces.

The collector base changed. Institutional budgets declined, as did the material available. The activities of the "professional" collectors faded. My focus went to the private collectors. The steady change in education became more apparent, and private collectors were now mostly entrepreneurial businessmen, lawyers, and doctors.

Librarians changed as well. Becoming more like MBAs, they no longer necessarily had any connection to the institutions or to the subjects collected but, instead, were managers. This caused a decline in support and donations of collections. The librarians, who had been able to lure 
collectors with their enthusiasm and knowledge of their specialties, were retiring; and collectors preferred selling their collections rather than giving them to an institution where the librarian knew little about their subject and had even less passion for it.

As far as operating a business, with the exception of rent and employee costs, the situation improved. Printing methods and communications became much cheaper, the photocopy machine saved enormous time, as would the fax machine later, and computers changed mailing list management, accounting, and eventually inventory records.

Advertising and public relations became factors in creating new collectors, but it was the auction houses that completely dominated this area. The dealers were not able to react to this area of marketing.

While book and manuscript dealers situated at ground level declined rapidly as leases came to an end, it was the auction houses that maintained high-visibility locations and were seen as user-friendly by requiring only a credit card to become a client.

The dealers' attitude that anyone who was interested in collecting their specialty would find them was understandable (and true to some degree), as they were forced by increased costs to move to upper-floor offices, to the suburbs, or to operate from their homes. The problem has been that although the seasoned collectors know how to find them, dealers do not bring new collectors into the field with such locations. Instead, they have to find other means; and from discussions with specialist dealers, they have generally not been as successful as they would like.

Auction catalogs were written for people with no specific knowledge of the collecting areas, whereas the dealers' catalogs were replete with abbreviations, references that only experienced collectors would understand, and continued in the tradition of treating rare book and manuscript collecting as a private club. No question asked at an auction 
house would be too stupid, but just reading dealers' catalogs, with all of the assumed knowledge behind the descriptions, was enough to make almost any prospective collector feel ignorant.

With the exception of advances in computers and the Internet, in particular, the present situation is, with a few exceptions, a logical continuation of these trends; and I can't be sanguine about the future.

The present is hard to define because it is constantly becoming the past, and today's actions should incorporate one's view of the future. We are more concerned than ever with creating new collectors, and although our New York gallery does not generate anywhere near the sales as Boston, the retail side in New York requires far more effort. Without that effort, we are not going to develop many new collectors. We have had a tremendous amount of publicity, both hard news and feature stories, in many national magazines and television interviews; and this has directly produced very little in creating new collectors. It's not just my talking about manuscripts and rare books, but people seeing them and reacting to the feelings they bring out that creates the collectors. Our New York gallery physically introduces people to a field they have never experienced, and the excitement when they discover they can actually own a letter or document of their favorite author or hero in history is very gratifying. We tell them the letter is not rare, and it may not even be a wonderful letter, but what is wonderful is they can take it home with them. Every once in a while, one of these people has turned into a significant collector; and a crucial point missed by many dealers, particularly those who opened galleries shortly after we did, especially in Beverly Hills, is that a retail gallery in a location that will attract significant visitors is very unlikely to financially break even on its own. A gallery is only viable when the dealer has the inventory and staff to follow up and develop people who initially come into the gallery and can maintain this part of the business, and all administration, in a location costing far less than the gallery. 
The excellent talk in Vienna by John Wronoski, "Why Johnny Can't Sell Books," had as its subtitle, "Education and the Future of the American Rare Book Trade." Education statistics at the college level certainly bear out the major change that has already taken place and likely will continue. Nationally, 12 percent of college graduates majored in English literature in 1963, and by 1993, this percentage had declined to four percent. Sixteen percent majored in the social sciences and history, and that declined to 11 percent in 1993, whereas the 11 percent majoring in business management has increased to 21 percent. In the most recent year for which statistics are available, two percent of males and three percent of females were majoring in English literature, and eight percent and 13 percent, respectively, in the social sciences and history. Even within these traditional fields of education that have produced people interested in collecting, the material taught has changed dramatically. Many colleges have replaced the required Western Civilization course with "Cultures, Ideas, and Values," a course based on notions of cultural parity with a mandated emphasis on race, gender, and class. At Stanford, this course leads to an upper-level history seminar titled "Black Hair as Culture's History," and quoting from the catalog, that course is described as addressing the issue of how black hair has "interacted with the black presence in this country and how it has played a role in the evolution of black society." "Religions in America," at Stanford, does not include the Catholic religion but examines Shamanism, the Peyote cult, and the Kodiak sect. Anthropology I, again quoting from the catalog, devotes its lectures to "language imperialism" and blames CNN for broadcasting in English to the entire world.

It is not just an educational background that differentiates tomorrow's prospective collectors from their predecessors (they are far more likely to be entrepreneurs, people who are used to challenging established ideas and rules, and unlikely to be people with inherited wealth), those 
that did not make it aren't comfortable spending it, particularly in a field that requires some self-assurance.

My own experience is that these entrepreneurs have a serious cultural clash with dealers who tell them about the "rules" of book collecting. I have personally been astounded, while assembling several large libraries, to be told by many dealers that I have to tell my collectors what and how to collect, that I have to "educate" them according to the established rules and criteria they must follow. Many dealers frequently assume that books I buy are for one particular client, and I am constantly and dogmatically told that this client should only have the rarest possible copy of every book, only on vellum, or only in the rarest binding. When I've asked why, the answer is invariably "because he can afford it!" And also the dealer has it in stock.

We have also experienced this attitude in a different version. We were recently seeking a major set of plate books and contacted a number of dealers. All but the one dealer who had a set told us to only get a perfect set with all the plates colored. The one set on the market was perfect except for four uncolored plates. Most dealers told us not to compromise by buying this set, but when we learned that the last fully colored set on the market was over 50 years ago, that no dealer knew of a privately owned perfect copy, and that our client would have to hope an institution sold its copy, he decided to compromise and enjoy it within his lifetime.

The worst example of discouraging a potentially fine collector involved a friend of ours who wanted to form a book collection in an area outside our fields of interest. I introduced her to several of the leading dealers and explained to them that she would likely become a major client. As far as I was concerned, they were the best in the field, but they completely discouraged her. She was told that the writers who interested her weren't the ones to collect; she was told who to collect, 
to buy all of their works whether they personally interested her or not, and not to collect a particular series if she wanted to be a "serious" collector (this was the series that initially interested her in book collecting). Fortunately, she has a strong will and needs no one's approval to follow her instincts; and after much encouragement to collect what interests her, not what these dealers told her she must collect, she has developed a very fine personal library. We recently purchased a piece for her for about $\$ 2$ million. When the first dealer we had introduced her to learned of this, he told her that he now considered her a serious collector and would like to establish a relationship. By then, of course, it was too late.

Of all the factors that I discuss tonight, I think this is the most important. The present and future collectors are interested in information, in alternatives, in options; and those dealers who treat prospective collectors with respect rather than condescension will succeed, while those who continue to believe that there are "rules" of book collecting and sneer at those who do not slavishly follow the dealers' own criteria, will not. I cannot emphasize strongly enough how struck I have been in the past few years by the dealers who have treated me with appalling condescension when offering me printed books.

I want to be very clear that I am not criticizing dealers giving advice. On the contrary, knowledgeable advice is the most important service a dealer can offer-and a major advantage dealers have over auction houses.

Advice about best editions, rarity, likelihood of obtaining pieces, condition, and so forth are what being a dealer is all about. I frequently discuss with potential new collectors what they can find in the areas that interest them, what is collectible and what is uncollectible, a general idea of likely costs, and when a unique acquisition opportunity is at hand.

My criticism is of dealers being dogmatic in imposing their own opinions and criteria on collectors - the dust jackets must be perfect, 
collecting Printing and the Mind of Man books is shallow, collecting high spots is to be condemned, and all the other condescending pronouncements a number of dealers make. Is it any wonder that a very successful person in his or her own field is completely put off when told about the rules he or she must follow to build a rare book collection?

Turning to an area where I think the present and future is more positive than the recent past, the material available has much improved, both in terms of quality and quantity. This, in part, is because many collections, such as the Norman Collection ${ }^{3}$, have come onto the market rather than going to institutions, and institutions in many cases have sold collections that were not relevant. I think this will continue in the future, and as today's collectors are even more put off by the attitude of some librarians than they are by the dealers, collections will continue to come back onto the market. As boards of trustees are more and more made up of businessmen rather than academics or socialites, the attitude will be to continue de-accessioning nonrelevant material.

There are two notable exceptions to this trend, both primarily in manuscripts. Two financiers have formed an incredibly broad and important Americana collection-something no one thought could be done-and they have done it by paying whatever has been necessary and by very aggressively going after collections in institutions and in private ownership before they came onto the market. Indications are that it is a permanent, long-term collection and will not come back onto the market in the foreseeable future.

The other collection is one that we have been forming. It is primarily composed of letters and manuscripts as well as rare books, and it is 
highly unlikely it will come back onto the market, at least not in my lifetime.

As with the availability of material, there have also been the beginnings of some positive changes among the dealers. There may be more streetlevel shops in retail locations now than there were just a few years ago. The trend has certainly reversed in London, with three dealers opening street-level locations just off Bond Street and one of them opening a second street-level shop in London.

Book fairs have been one of the mainstays of many dealers for the past decade or more. A constant complaint, however, is that dealers sell only to other dealers, and they are not meeting new collectors. I don't see what is necessarily wrong with the reality that book fairs have, to a large extent, become a very efficient way for dealers to exchange material principally on the basis of their clients' interests. Book fairs declined as a major source of new collectors when the long-established dealers with large collector bases either dropped out of book fairs, went out of business, or stopped inviting their clients to the fairs. The unfortunate reality is that it makes no sense for a dealer who spends large amounts on advertising and hundreds of thousands of dollars for a prime location to attract and develop new collectors to invite their clients to book fairs to meet competing dealers who do little advertising, operate out of their homes, and attract few, if any, visitors to book fairs. George Goodspeed consistently refused to participate, even in a token way, in the Boston Book Fair. Why should he, he said, allow his name to attract collectors to meet his competitors when his competitors didn't have any clients he could meet?

Other factors are the type of advertising and the difficulty in getting the right kind of publicity. All of us who love this field suffer from the illusion that if only everyone knew about it, they would come running. Unfortunately, this just isn't the case. 
The chronic complaint from PR people is that dealers, whether antique, art, or rare book, have little idea of what will interest the media. I have been regularly involved with publicity for the Winter Antiques Show, and it is not all that different from the situation at book fairs. Most of the time, the dealers focus on expensive pieces, or very rare ones, when what the media want is the human-interest side, not rare books as printing artifacts. One of the Boston Book Fair's PR bonanzas occurred when the media decided that the thief who stole books from the John Adams House might turn up at the Boston Book Fair to sell them. A ridiculous idea, but indicative of popular media thinking.

Having mentioned the Winter Antiques Show, I want to discuss the subject of bringing autographs and rare books into venues where people are collectors in other fields but might become collectors in our field. The major antique shows, of which there are five or six in this country, are unlike book fairs in that a certain number of dealers from each specialty are included, and the major shows already have their quota of manuscript and rare book dealers. The best shows make great efforts to balance different types of material. If the show is satisfied with the exhibitors they already have in a specialty, a new applicant has to wait for someone to drop out or no longer fulfill the criteria of the show management. Most of these shows also require that new exhibitors have a retail presence and bring a following of collectors with them. The present exhibitors want to know that every dealer is bringing in a following to the show, the same as he or she is. These shows are also very expensive relative to book fairs, many costing $\$ 25,000$ to $\$ 50,000$. There are many antique shows, however, that cost about the same as book fairs and are anxious to have new exhibitors.

Another area dealers should explore is the specialty show, for example, military history shows, which traditionally have exhibitors showing artifacts. If people are collecting Civil War artifacts, they are likely to 
be interested in Civil War books and letters. We exhibited at a meeting of the Napoleonic Society of America some years ago; it was very inexpensive, and we were quite pleased with the results. In many fields, there seem to be focused groups like this that hold interesting meetings and dealers should consider them.

It can be argued that ignorance of our fields is our greatest competition, not other dealers. It can also be argued, I think more effectively, that our greatest competition, in most areas, is the auction house, which now dominates many of the antique art-collecting areas. Their financial power and combined administrative operations, advertising budgets, and PR ability, as well as locations, are unimaginable to dealers in virtually any of the fields, except perhaps paintings and jewelry. The auction houses set out to make their auctions unintimidating, and they were successful. For an unsure potential collector who just wants to browse, it is hard to equal the auction houses in terms of what, in the retail business, is called threshold anxiety. Anyone can walk in, look at the exhibitions, and buy a catalog. No one is going to ask you questions; people are going to leave you alone. All it takes to bid is a credit card.

Dealers, however, have a great advantage in personal service. We have a wealth of knowledge and experience the auction houses cannot match, and, most important, we have the ability to establish personal relationships and respond individually to the collector's needs. When you telephone a dealer, no one asks what your client number is or what your paddle number was.

Dealers also have the advantage of offering immediate reality rather than future hope. The collector can buy or sell something immediately and not have to hope that in the future they will be successful.

Recent news from the auction houses offering financing to dealers for a percentage of the profits can be seen as both positive and negative, but 
the sharply increased emphasis on private treaty sales is very threatening to dealers. The auction houses in these situations directly compete with the role of dealers in offering important pieces and collections for sale at fixed prices, and they have very ambitious plans. The target figures for the book department in one of the major houses far exceed those for almost any dealer's annual sales; these are not auction figures, these are direct-sale figures. This does illustrate one of their great weaknesses: they are run by business administrators, not specialists. To set a quota on how much the book department has to sell directly is ridiculous; the department can't control any more than it already does the amount of material it brings in for sale. Setting direct-sales targets may work at Bloomingdale's, but won't work with manuscripts and rare books.

The hottest topic in the future of our field is Sotheby's Internet auction. I think the issues it raises are more complex than those which dealers are discussing, and if their scheme is successful, it will have profound effects. I don't have an opinion as to whether it is a good or bad idea; it depends on the situation of individual dealers. Unfortunately, many of the dealers embracing it, and most of those condemning it, don't seem to have thought out all the implications.

On the surface, it is straightforward: the dealers supply the material and the expertise, and Sotheby's supplies the market and business administration. This arrangement may be the answer to one of the major dealer concerns of the present and worries about the futurewhere are new collectors going to come from? Next to concerns about the lack of new collectors, though, dealers have concerns about the lack of good material. It seems likely, therefore, that dealers will be inclined to put into the Internet auctions material they can't sell to their own clients; and if most do this, Sothebys.com could become an efficient dealer-to-dealer market, like an ongoing book fair without all the work. 
A major question is what quantity and quality of new collectors Sotheby's will introduce to autographs and rare books? They are certainly in a better position than anyone else in terms of crossover interests from other fields, advertising, and public relations resources. One indication of how well they might do is how much of what is presently sold in their auctions goes to collectors not known to dealers. With manuscripts, much of what is sold goes to dealers acting as agents or to collectors who are known to most dealers. Online bidding, perhaps, would increase new bidders as I think the Internet has increased the market for antiquarian books. If they materialize, will these bidders, along with buyers unknown to dealers, be the bonanza every dealer who has signed up seems to be counting on? Will these bidders want to buy directly from a dealer or only through the auction process?

Another major question is what will the effect be on dealers whose competitive advantages have been the immediate availability of material, knowledge, and service now that they are seen as virtual partners in the auction process? I maintain that the auction process is the ultimate competition for dealers. By embracing and becoming a part of the auction process, dealers may find many clients wanting them to put material at auction rather than buying it privately from the dealer as they have done in the past. The auction process is very seductive. There is the frequently erroneous reassurance that there is always a knowledgeable underbidder. We all know collectors who will only buy at auction or will pay more for important pieces if they think there is an underbidder, and on the Internet that reassurance of an underbidder may not be as apparent as in a salesroom.

How many people offering participating dealers material for sale may now treat the dealers as a branch office of the auction house and want the material put up for auction? In Paris, all of the dealers have complained that soon after they became experts for auctions, people only 
wanted to sell through them at auction and not sell directly to them.

Dealers will be giving up their two strongest points, immediacy and service, but will be getting marketing and efficient business administration. They will become a part of the process that is most threatening to them. They believe that their reserve price will ensure them profit. But will Sotheby's collectors pay both the dealers' markup and Sotheby's commission? Or will Sotheby's have to restrict dealers whose reserves frequently aren't met, force them to forgo their needed markup, and sell the item for what it will bring at that moment and not necessarily when the right collector is able to acquire it?

The last area I will discuss is the one in which I have the least confidence: the Internet. I must admit I never realized its importance and potential until very recently when the evidence became overwhelming. Fortunately for ABAA members, the organization's leadership has been extraordinary among all of the antique and art organizations in not only making information available to members but in helping create Web sites for them.

I don't see how any active dealer can avoid having a Web site containing basic information about the dealer's specialty, catalogs, and contact information. Advertisements with a Web site address can expand the influence and information of the ad to include everything you want to communicate.

The general public's interest and fascination with the Internet is one of, if not the greatest, phenomena of our time. I am amazed that our clients-some of them very busy executives-browse the Web. Many people seem to live on it. A Web site's importance is so disproportionate to the effort involved, thanks to the ABAA, that most dealers should have a basic listing. 
In preparation for this talk, I have been very impressed with the tremendous amount of business in selling antiquarian books on the Internet. Most of the sales are books sought for informational rather than artifact value. It also appears that these sales are being made because of people's access to the Web and the dealers' offerings, and not at the expense of in-shop or direct sales. These appear not to have declined.

On the negative side, book scouts who formerly had to sell to dealers who occupied shops and issued catalogs are not on an equal footing in using the Web, and anyone now can become a dealer. The dealer with high operating cost cannot charge any more than the dealer with the lowest. Also, dealers with their inventories on the Web tell me that people offering books for sale too frequently check their retail price first and expect an unreasonably high percentage.

I have heard many different opinions about offering rare books and autographs on the Web. It is obvious that many rare books won't look as rare when a potential buyer is able to see a listing of most of the copies on the market. If condition is equal, all prices will be brought down to the level of the least expensive copy; and that will likely be offered by the dealer with the lowest expenses or the dealer with the highest volume of sales. Hopefully, this competition that may cause a deflation in prices won't be compensated for by an inflation of condition statements.

My personal view happens to be the present view of most of the rare book dealers I talked to. The Internet is not the place to offer manuscripts and rare books. I suspect this view won't be as strongly held a year from now. I like the "entertainment value" of visiting bookshops. I like to read nicely designed catalogs, not browse a Web site, and I like to talk to a dealer and share our excitement and enthusiasm. As a dealer, I like the interaction with collectors when we sell interesting pieces. I like to visit collectors and show them pieces and share their excitement and enthusiasm. This is an important part of being a dealer 
for almost every dealer I spoke with. I hope this won't change. I hope people won't want to buy exciting and interesting pieces through a computer, but I think the future will prove me wrong to some degree.

I have given a lot of thought on how to conclude this talk. I found some great quotes on what bookshops will need to do in the future if they are to survive, all very appropriate, but written 80 years ago by A. Edward Newton. I thought I might paraphrase Winston Churchill's quote from the opening: Those who do not change the way they sell history will be condemned to becoming history.

But the bottom line is that we all face very serious changes in the way we operate our businesses. We have only to look at Western Union and letterpress printing shops to see what can happen. Many of the business changes can be utilized, like the Internet, to cut costs and possibly develop new clients-our greatest challenge.

But the good news is that at the core of all our activities are the artifacts of human history: the letters, the manuscripts, the books that record, chronicle, and preserve the history of civilization. No matter what the future business challenges, we are in an honorable profession and should be thankful to play an important role in preserving the history of our past and the chronicle of our present. 